\title{
Nitrification Inhibition Potential of Brachiaria humidicola
}

\author{
H. M. Meena • M. S. Sachdev • K. M. Manjaiah • \\ M. L. Dotaniya
}

Received: 17 April 2013/Revised: 11 July 2013/ Accepted: 22 October 2013/Published online: 12 March 2014

(C) The Author(s) 2014. This article is published with open access at Springerlink.com

\begin{abstract}
An incubation experiment was conducted to determine the nitrification inhibition potential of Brachiaria humidicola (B. humidicola) and their effect on nitrification process. The pots soil was mixed $2 \mathrm{mg}$ of nitrogen through ammonium sulphate. Seven treatments were evaluated viz. control, four root extracts of B. humidicola called as biological nitrification inhibitors (BNIs) (i.e., $70 \%$ ethyl alcohol, $40 \%$ ethyl alcohol, phosphate buffer solution and $2 \mathrm{M} \mathrm{KCl}$ salt solution extracts) and two standard chemical inhibitors i.e. dicyandiamide and neem oil coating. The amount of $\mathrm{NH}_{4}{ }^{+}-\mathrm{N}$ was reduced 20.66-11.91 $\mathrm{\mu g} \mathrm{g}^{-1}$ soil and $\mathrm{NO}_{3}{ }^{-}$-N increased 28.89-31.18 $\mu \mathrm{g} \mathrm{g}^{-1}$ soil from 14th to 22nd day time interval. Percent nitrification inhibition was more in BNIs (70 and $40 \%$ alcohol extract) treated soils compared to plant based and synthetic nitrification inhibitors. The nitrification inhibition by $B$. humidicola also varied it was maximum (64.71\%) observed at 14th day over 22nd day $(49.63 \%)$.
\end{abstract}

Keywords Brachiaria humidicola . BNIs ·

Nitrification inhibition potential

H. M. Meena $(\bowtie)$

Central Arid Zone Research Institute, Jodhpur 342 003, India

e-mail: hmmeena82@gmail.com

M. S. Sachdev $\cdot$ K. M. Manjaiah

Division of Soil Science and Agricultural Chemistry, IARI,

New Delhi, India

M. L. Dotaniya

Indian Institute of Soil Science, Nabibagh, Berasia Road,

Bhopal 462 038, India

\section{Introduction}

Nitrogen is the most precious nutrient for crop growth and yield. Nitrification is a major pathway for nitrogen loss both in agricultural and natural system [1-3]. Nitrification results in transformation of the relatively immobile ammonium nitrogen $\left(\mathrm{NH}_{4}{ }^{+}-\mathrm{N}\right)$ to highly mobile nitrate $\left(\mathrm{NO}_{3}{ }^{-} \mathrm{N}\right)$ which promotes $\mathrm{N}$ losses through leaching of $\mathrm{NO}_{3}{ }^{-}-\mathrm{N}$ as well as gaseous $\mathrm{N}$ emission caused potentially cascade of environmental and health problems [4-6]. Nitrous oxide $\left(\mathrm{N}_{2} \mathrm{O}\right)$ is one of the major biogenic green house gases contributing to global warming, produced primary from denitrification processes in agricultural system [7]. Nitrification acts as a key process in determining fertilizer use efficiency by crops as well as nitrogen losses from soils. Arrest of N-loss in the crop fields can help in increasing $\mathrm{N}$ utilization. It is possible with the use of nitrification inhibitors either natural or synthetic.

Nitrifies activity increased by the availability of $\mathrm{NH}_{4}{ }^{+}-$ $\mathrm{N}$ in soils either from fertilizer or released by the mineralization of soil organic matter [8]. The dicyandiamide (DCD) nitrification inhibitor improved the $\mathrm{N}$ fertilizer use efficiency and decreased $\mathrm{NO}_{3}{ }^{-}-\mathrm{N}$ losses in citrus [9]. So, it helped to minimize the economic and environmental risks. DCD and neem cake were evaluated by for $\mathrm{N}$ inhibiting efficiency of prilled urea-derived $\mathrm{NH}_{4}{ }^{+}-\mathrm{N}$ in wheat [10]. It also reported that DCD was better than neem cake. The nitrogen use efficiency was $29 \%$ in uncoated fertilizer and $46 \%$ in polyolefin coated fertilizer with DCD was applied as a slow release fertilizers; especially coated urea with DCD significantly increase the $\mathrm{N}$ use efficiency in tea [11]. DCD was able to inhibit the nitrification process during the decomposition of crop residues [12].

Many tropical grasses having nitrifies activity, and recently $B$. humidicola attracted the attention of researcher 
due to its inhibiting nitrification process, through root exudates [3]. It also reported that an effective nitrification inhibitor properties found in the root-exudates of the tropical forage grass $B$. humidicola. Seed germination of $B$. humidicola is a long process with very low germination rate, i.e. about $14 \%$. Its chemical composition called "brachialactone" contains cyclic diterpene with a unique 5-8-5-membered ring system and a $\gamma$-lactone ring. It contributed 60-90 \% of the inhibitory activity released from the roots. Root exudates of $B$. humidicola concentrated and mixed with $\mathrm{N}$ fertilizers to minimize nitrification process and increase $\mathrm{N}$ use efficiency (NUE) in crops. The age and developmental stage of $B$. humidicola are very important in terms of root exudates quantity, and normally root exudates decreases with increasing plant age, especially after flowering which is coincidence with a reduction in microbial number [13].

The application of root extract did not change ammonium nitrogen content in soil up to 8th day [14]. Later on it observed that the ammonium oxidizing bacteria (AOB) populations and $\mathrm{N}_{2} \mathrm{O}$ emission from the soil were significantly lower in the soil where $B$. humidicola has been grown compared to $B$. decumbens and $M$. minutiflora. Sorghum had significant BNIs capacity, releasing 20 allylthiourea units (ATU) $\mathrm{g}^{-1}$ root dry wt day ${ }^{-1}$. BNIs compound release from roots is a physiologically active process, stimulated by the presence of $\mathrm{NH}_{4}{ }^{+}$and growth stages of crops [15]. The percent nitrification inhibition of neem oil which was ranging from 4 to $30.9 \%$ [16]. Use of BNIs compared to synthetic nitrification inhibitors i.e. as nitrapyrin, (DCD), and 3,4-dimethyl pyrazole phosphate showed many advantages in regards to NUE. The objective of the present study was to investigate the effect of root extracts of $B$. humidicola in relation to nitrification inhibition potential $[17,18]$.

\section{Materials and Methods}

\section{Extraction Root Extracts from B. humidicola}

Brachiaria humidicola was planted in pots having a mixture of soil and sand in the ratio of $4: 1$. Temperature was maintained at $20-26{ }^{\circ} \mathrm{C}$ during the growth period in greenhouse conditions. The plants of $B$. humidicola were uprooted after flowering stage from the pots and the roots were separated from the plants, cleaned and used for extraction. The macerated roots of $B$. humidicola were extracted with different solvents (70, $40 \%$ ethyl alcohol, salt solution and phosphate buffer solution).

Incubation Study and Soil Analysis

A laboratory experiment was conducted for 22 days to determine the nitrification inhibition potential of root extracts. Ammonium sulphate was used as a source of nitrogen. Soil was collected from field of Indian Agricultural Research Institute (IARI), New Delhi, India. Soil samples were air-dried, ground and passed through a $2 \mathrm{~mm}$ sieve. Ten grams soil were mixed thoroughly with $10 \mathrm{~g}$ of quarts sand and placed in $250 \mathrm{ml}$ conical flasks and treated with $1 \mathrm{ml}$ solution containing $2 \mathrm{mg}$ of nitrogen. Seven treatments were applied viz. control, four root extracts of B. humidicola called as biological nitrification inhibitors (BNIs) (i.e., $70 \%$ ethyl alcohol, $40 \%$ ethyl alcohol, phosphate buffer solution and $2 \mathrm{M} \mathrm{KCl}$ salt solution extracts) and two standard chemical nitrification inhibitors (NI) i.e. DCD and neem oil coating. Water holding capacity was maintained at field capacity during the course of study. Flasks were covered with aluminum foil caps having a central hole of $1 \mathrm{~mm}$ diameter and were incubated in incubator at $25^{\circ} \mathrm{C}$.

Soil samples collected at 14 th and 22nd day after incubation and were extracted with $2 \mathrm{M} \mathrm{KCl}$ solution (soil:solution, 1:5). Nitrogen content in extract was determined by steam distillation [19]. The nitrification efficacy of extracts was determined by the technique materials and methods of Bundy and Brenner (1966) was used [20]. Soils samples analyzed for mineral nitrogen (ammonium $\mathrm{N}$ and nitrate $\mathrm{N}$ ). The percent inhibition potential of the extracts as well as the standard inhibitors was computed.

\section{Results and Discussion}

Mineral: $\mathrm{NH}_{4}{ }^{+}-\mathrm{N}$ in Soil

In the study, $\mathrm{NH}_{4}{ }^{+}-\mathrm{N}$ in soil were significantly influenced by BNIs and NI. The $\mathrm{NH}_{4}{ }^{+}-\mathrm{N}$ in soil were highest in case of DCD $33.62 \mu \mathrm{g} \mathrm{g}^{-1}$ soil and in $70 \%$ alcohol extract $\left(26.19 \mu \mathrm{g} \mathrm{g}^{-1}\right.$ soil) compared to rest of the treatments. Nitrification process was highly significant with time. The $\mathrm{NH}_{4}{ }^{+}-\mathrm{N}$ was higher $\left(20.66 \mu \mathrm{g} \mathrm{g}^{-1}\right.$ soil $)$ at 14 th day incubation period compared to $22 \mathrm{nd}$ day $\left(11.91 \mu \mathrm{g} \mathrm{g}^{-1}\right.$ soil) (Table 1). Nitrogen remained in the soil in inorganic form, $\mathrm{NH}_{4}{ }^{+}-\mathrm{N}$, for a longer period at the spots where there was a growth of $B$. humidicola as compared to the adjacent spots having no growth of $B$. humidicola. The $\mathrm{NH}_{4}{ }^{+}-\mathrm{N}$ in soil was higher under DCD and $70 \%$ alcohol extract, which clearly showed that the nitrification process was regulated more through DCD and $70 \%$ alcohol extract due to suppressed growth of nitrifies bacterial population. The root exudates and soil extracts of $B$. humidicola suppressed AOB populations [14]. The synthetic nitrification inhibitors such as AT, nitrapyrin or DCD which are specific to the ammonia monooxygenase enzymatic pathway [21]. When DCD was applied along with ammonium sulphate nitrate 
Table 1 Effect of Brachiaria humidicola root extracts (BNIs) and nitrification inhibitors on $\mathrm{NH}_{4}{ }^{+}-\mathrm{N}, \mathrm{NO}_{3}{ }^{-}-\mathrm{N}$ and percent nitrification inhibition in soil

\begin{tabular}{|c|c|c|c|c|c|c|c|c|c|}
\hline \multirow[t]{3}{*}{ Treatments } & \multicolumn{3}{|c|}{$\mathrm{NH}_{4}^{+}-\mathrm{N}\left(\mu \mathrm{g} \mathrm{g}^{-1}\right.$ soil $)$} & \multicolumn{3}{|c|}{$\mathrm{NO}_{3}^{-}-\mathrm{N}\left(\mu \mathrm{g} \mathrm{g}^{-1}\right.$ soil $)$} & \multicolumn{3}{|c|}{ Nitrification inhibition (\%) } \\
\hline & \multicolumn{3}{|c|}{ Time (days) } & \multicolumn{3}{|c|}{ Time (days) } & \multicolumn{3}{|c|}{ Time (days) } \\
\hline & 14 & 22 & Mean & 14 & 22 & Mean & 14 & 22 & Mean \\
\hline $\mathrm{T}_{1}(70 \%$ alcohol extract $)$ & 30.35 & 22.02 & 26.19 & 5.85 & 18.76 & 12.31 & 131.37 & 89.12 & 110.25 \\
\hline $\mathrm{T}_{2}(40 \%$ alcohol extract $)$ & 14.53 & 8.68 & 11.61 & 10.01 & 24.4 & 17.21 & 118.18 & 70.86 & 94.52 \\
\hline $\mathrm{T}_{3}$ (salt solution extract) & 12.15 & 5.64 & 8.90 & 44.14 & 33.53 & 38.84 & 9.89 & 42.38 & 26.14 \\
\hline $\mathrm{T}_{4}$ (buffer solution extract) & 9.66 & 6.23 & 7.95 & 43.44 & 42.84 & 43.14 & 12.06 & 11.12 & 11.59 \\
\hline $\mathrm{T}_{5}$ (neem oil coating) & 20.06 & 6.23 & 13.15 & 24.22 & 31.36 & 27.79 & 73.09 & 48.34 & 60.72 \\
\hline $\mathrm{T}_{6}(\mathrm{DCD})$ & 44.35 & 22.89 & 33.62 & 27.34 & 30.59 & 28.97 & 63.12 & 50.88 & 57.00 \\
\hline $\mathrm{T}_{7}$ (control) & 13.55 & 11.69 & 12.62 & 40.30 & 45.27 & 42.79 & 45.30 & 34.74 & 40.02 \\
\hline Mean & 20.66 & 11.91 & & 27.09 & 32.39 & & 64.71 & 49.63 & \\
\hline $\operatorname{LSD}(P<0.05)$ & $\begin{array}{l}\text { Treatn } \\
\text { Time } \\
\text { Treatm }\end{array}$ & $\begin{array}{l}=4.43 \\
7 \\
\times \text { time }\end{array}$ & & $\begin{array}{l}\text { Treatn } \\
\text { Time } \\
\text { Treatn }\end{array}$ & $\begin{array}{l}=1.01 \\
54 \\
\times \text { time }\end{array}$ & & $\begin{array}{l}\text { Treatme } \\
\text { Time }= \\
\text { Treatme }\end{array}$ & $\begin{array}{l}3.00 \\
\text { time }=\end{array}$ & \\
\hline
\end{tabular}

(ASN), there were significantly higher levels of $\mathrm{NH}_{4}{ }^{+}-\mathrm{N}$ in the substrate than in the ASN treatment alone, for at least 100 days [9].

The $\mathrm{NH}_{4}{ }^{+}-\mathrm{N}$ in soil were distinctly higher at 14 th days as compared to that of 22nd days (Fig. 1). The inhibitory effect of DCD and $70 \%$ alcohol root extract was significant up to 14th day as compared to 22 nd day. A complete suppression of nitrification by $20 \mathrm{U}$ of BNIs per gram of soil which led to the retention of the added $\mathrm{N}$ [200 $\mathrm{mg} \mathrm{N}$ as $\left.\left(\mathrm{NH}_{4}\right)_{2} \mathrm{SO}_{4}\right)$ ] in $\mathrm{NH}_{4}{ }^{+}-\mathrm{N}$ form during a 55-day incubation. Nearly $40 \%$ nitrification inhibition of soil was observed when applied BNIs released from sorghum to the soil reach at $10 \mathrm{ATU}^{-1}$ soil [22].

\section{Mineral: $\mathrm{NO}_{3}{ }^{-}-\mathrm{N}$ in Soil}

On the contrary, $\mathrm{NO}_{3}{ }^{-}-\mathrm{N}$ also measured in soil during incubation study, among the treatments highest $\mathrm{NO}_{3}{ }^{-} \mathrm{N}$ (43.14 $\mu \mathrm{g} \mathrm{g}^{-1}$ soil) in soil was recorded in buffer solution extract. The $\mathrm{NO}_{3}{ }^{-}-\mathrm{N}$ in soil increased with time, at $22 \mathrm{nd}$ day $\left(21.69 \mu \mathrm{g} \mathrm{g}^{-1}\right)$ than 14 th day $\left(19.26 \mu \mathrm{g} \mathrm{g}^{-1}\right)$ (Table 1 ; Fig. 1). The nitrification process was inhibited by the root exudates of $B$. humidicola. The results support the hypothesis that $B$. humidicola suppressed nitrification and $\mathrm{N}_{2} \mathrm{O}$ emissions through an inhibitory effect on the AOB populations [14]. Soil collected from field plots of 10 yearold high-BNIs genotypes of $B$. humidicola, showed a near total suppression (more than $90 \%$ ) of nitrification; most of the soil inorganic $\mathrm{N}$ remained in the $\mathrm{NH}_{4}{ }^{+}$form after 30 days of incubation [17, 18]. Nitrification inhibitory activity in root tissues extracts of $B$. humidicola was significantly affected mineral $\mathrm{NO}_{3}{ }^{-}-\mathrm{N}$ in soil [23].

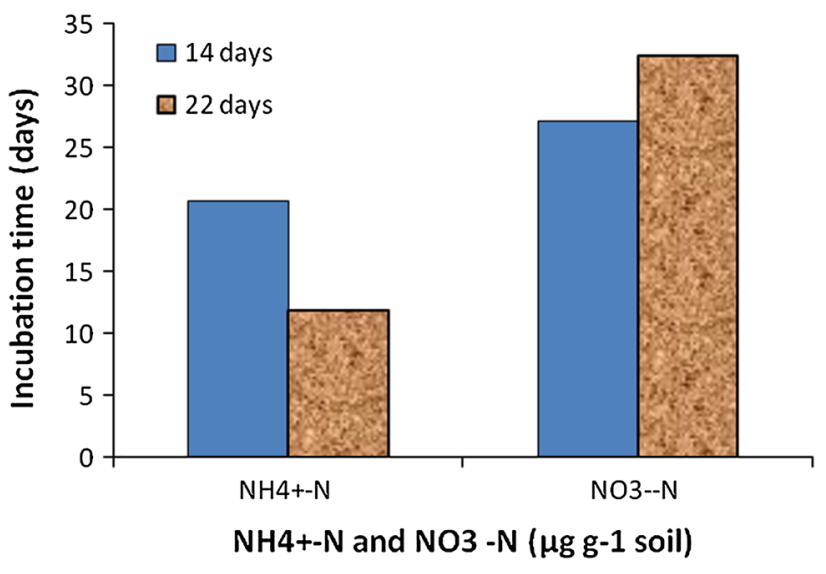

Fig. 1 Effect of incubation time on $\mathrm{NH}_{4}{ }^{+}-\mathrm{N}$ and $\mathrm{NO}_{3}{ }^{-}-\mathrm{N}$ in soil

Nitrification Inhibition

The maximum percent nitrification inhibition observed in $70 \%$ alcohol extract (110.25\%) followed by $40 \%$ alcohol $(94.52 \%)$, neem oil coating $(60.72 \%)$, DCD (57\%) (Table 1; Fig. 2). There was more percent nitrification inhibition in soil up to 14 th day $(64.71 \%)$ compared to 22nd days $(49.63 \%)$. The synthetic nitrification inhibitor (DCD) suppress more than or equal $80 \%$ on soil nitrification in the concentration range of $10-50 \mu \mathrm{g} \mathrm{g}^{-1}$ soil at $20{ }^{\circ} \mathrm{C}$ incubation temperature $[22,23]$. The BNIs activity from root exudates was more effective in inhibiting nitrification process in soils than the standard nitrification inhibitor, nitrapyrin (at $4.5 \mathrm{ppm}$ ) during the period of the experiment [18]. The isolated compound brachialactone act as a nitrification inhibitor having $\gamma$-lactone ring. It reduced 


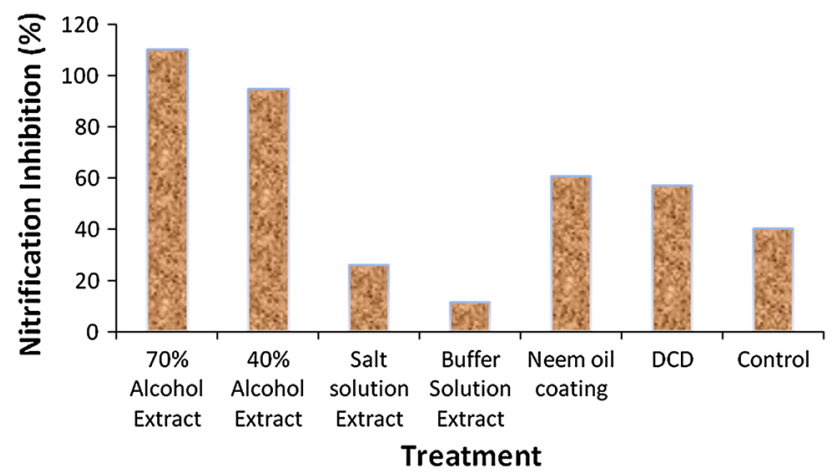

Fig. 2 Brachiaria humidicola root extracts (BNIs) and nitrification inhibitors effect on nitrification inhibition during incubation

the nitrification process $60-90 \%$ and also the nitrification microbial population drastically [13].

\section{Conclusion}

It may be inferred from our study that the treatment of $70 \%$ alcohol root extracts of $B$. humidicola showed higher suppression of nitrification process as compared to synthetic inhibitors like DCD. Therefore, it can be used as a natural nitrification inhibitor to check $\mathrm{N}$-related problems, like ground water pollution, $\mathrm{N}_{2} \mathrm{O}$ emission, and loss of $\mathrm{N}$-inputs from agricultural fields. Further, BNIs were also effective in nitrification inhibition as compare to the synthetic nitrification inhibition DCD as well as the neem oil coating of fertilizers. These BNIs isolated as crude extracts of roots of B. humidicola can be used as a coating material on $\mathrm{N}$ fertilizers.

Open Access This article is distributed under the terms of the Creative Commons Attribution License which permits any use, distribution, and reproduction in any medium, provided the original author(s) and the source are credited.

\section{References}

1. Glass ADM (2003) Nitrogen use efficiency of crop plants physiological constraints upon nitrogen absorption. Crit Rev Plant Sci 22:453-470

2. Giles J (2005) Nitrogen study fertilizes fears of pollution. Nature 433:791

3. Subbarao GV, Nakahara K, Hurtado MP, Ono H, Moreta DE, Salcedo AF, Yoshihashi AT, Ishikawa T, Ishitani M, Kameyama MO, Yoshida M, Rondon M, Rao IM, Lascano CE, Berry WL, Ito O (2009) Evidence for biological nitrification inhibition in Brachiaria pastures. Proc Natl Acad Sci USA 106:17302

4. Galloway JN, Townsend AR, Erisman JW, Bekunda M, Cai Z, Freney JR, Martinelli LA, Seitzinger SP, Sutton MA (2008) Transformation of the nitrogen cycle: recent trends, questions and potential solutions. Science 320:889-892

5. Schlesinger WH (2009) On the fate of anthropogenic nitrogen. Proc Natl Acad Sci USA 106:203-208
6. Leninger S, Urich T, Schloter M, Schwark L, Qi J, Nicol GW (2006) Archaea predominate among ammonia-oxidizing prokaryotes in soils. Nature 442:806-809

7. Kroeze C (1994) Nitrous oxide and global warming. Sci Total Environ 143:193-209

8. Robinson JB (1963) Nitrification in a New Zealand grassland soil. Plant Soil 19:173-183

9. Serna MD, Legaz F, Millo EP (1994) Efficacy of dicyandiamide as a soil nitrification inhibitor in citrus production. Soil Sci Soc Am J 58:1817-1824

10. Joseph PA, Prasad R (1993) The effect of dicyandiamide and neem cake on the nitrification of urea-derived ammonium under field conditions. Biol Fertil Soils 15(2):149-152

11. Han WY, Ma LF, Shi YZ, Ruan JY, Kemmitt (2008) Nitrogen release dynamics and transformation of slow release fertiliser products and their effects on tea yield and quality. J Soil Sci Food Agric 88(5):839-846

12. Chaves B, Opoku A, Neve S, Boeckx P, Cleemput O, Hofman G (2006) Influence of DCD and DMPP on soil N dynamics after incorporation of vegetable crop residues. Biol Fertil Soils 43(1): $62-68$

13. Liljeroth E, Baath E (1988) Bacteria and fungi on roots of different barley varieties (Hordeum vulgare L.). Biol Fertil Soils 7:53-57

14. Ishikawa T, Subbarao GV, Ito O, Okada K (2003) Suppression of nitrification and nitrous oxide emission by the tropical grass Brachiaria humidicola. Plant Soil 255:413-419

15. Zakir HAKM, Subbarao GV, Pearse SJ, Gopalakrishnan S, Ito O, Ishikawa T, Kawano N, Nakahara K, Yoshihashi T, Ono H, Yoshida M (2008) Detection, isolation and characterization of a root-exuded compound, methyl 3-(4-hydroxyphenyl) propionate, responsible for biological nitrification inhibition by sorghum (Sorghum bicolor). N Phytol 180:442-451

16. Kumar R, Devakumar C, Sharma V, Kakkar G, Kumar D, Panneerselvam P (2007) Influence of physicochemical parameters of neem (Azadirachta indica) oils on nitrification inhibition in soil. J Agric Food Chem 55(4):1389-1393

17. Subbarao GV, Ishikawa T, Ito O, Nakahara K, Wang HY, Bertry WL (2006) A bioluminescence assay to detect nitrification inhibitors released from plant roots: a case study with Brachiaria humidicola. Plant Soil 288:101-112

18. Subbarao GV, Ishikawa T, Nakahara K, Ito O, Rondon M, Rao IM, Lascano C (2006) Characterization of biological nitrification inhibition (BNI) capacity in Brachiaria humidicola. Jpn Int Res Cent Agric Sci 51:99-106

19. Bremner JM, Keeney DR (1966) Determination and isotope ratio analysis of different forms of nitrogen in soils: 3. Exchangeable ammonium, nitrate and nitrite by extraction-distillation methods. Soil Sci Soc Am Proc 30:577-582

20. Bundy LG, Bremner JM (1974) Effect of nitrification inhibitors on transformation of urea nitrogen in soil. Soil Biol Biochem 6:369-376

21. McCarty GW (1999) Modes of action of nitrification inhibitors. Biol Fertil Soils 29:1-9

22. Subbarao GV, Nakahara K, Ishikawa T, Ono H, Yoshida M, Yoshihashi T, Zhu Y, Zakir HAKM, Deshpane SP, Hash CT, Sehrawat KL (2012) Biological nitrification inhibition (BNI) activity in sorghum and its characterization. Plant Soil. doi: org/10.1007/s11104-012-1419-9

23. Gopalakrishnan S, Subbarao GV, Nakahara K, Yoshihashi T, Ito O, Maeda I, Ono H, Yoshida M (2007) Nitrification inhibitors from the root tissues of Brachiaria humidicola, a tropical grass. J Agric Food Chem 55:1385-1388 